\title{
Radon in the Dwellings: Causes and Prevention
}

\author{
M. Shakir Khan
}

Department of Physics, College of Science, Al-Zulfi, Al-Majmaah University, Saudi Arabia

* Corresponding author email: mskhan.amu@gmail.com, ms.khan@mu.edu.sa

Received: 14 October 2017 / Revised: 29 October 2017 / Accepted: 30 October 2017 / Published: 5 November 2017

\begin{abstract}
The problem of radon in dwellings gained importance in 1984 after an incidence in Pennsylvania, USA; thereafter several measuring techniques have been developed and national survey programs were started throughout the world for monitoring radon levels by government authorities. The lots of work have done by researchers in this field throughout the world. Several developed countries have given guidelines for initiating action to reduce radon levels if found beyond permissible level. The main aim of this article to provide public awareness about the health hazards posed by radon, which is naturally occurring invisible inert gas in the dwellings that is not be detected by human senses.
\end{abstract}

Keywords: Radon gas, Dwellings, Causes \& Prevention

\section{Introduction}

Radon $\left({ }_{86} \mathrm{Rn}^{222}\right)$ is a naturally occurring radioactive inert gas, which is ubiquitous in the environment both indoor and outdoor. It is colorless, odorless, and tasteless. Therefore, its presence cannot be detected by human senses. Radon is the heaviest of all noble gases, being denser than air. Therefore, it tends to settle in lower and closed areas, where air is still and can concentrate in poorly ventilated areas such as attics, basements, caves, mines etc. We inhale radon gas continuously along with other gases present in air while breathing. It is the largest contributor of the background radiation and contributes more than $50 \%$ of total absorbed radiation dose [1-2]. We are constantly exposed to the radioactivity of radon and its progenies in homes, offices or outside because of its natural presence. Inhalation of excess of radon and its progenies may even be carcinogenic to humans [3].

There are many epidemiological studies carriedout all around the world on uranium mineworkers and dwellers have clearly established a link between radon levels and lung cancer deaths prevalent in them due to prolonged inhalation of radon and its progeny [2-10]. Radon is a leading cause of lung cancer after smoking if it is present at enhanced levels beyond the permissible limit [2, 4]. Radon testing and estimation is the dwellings and corrective action has been mandatory in several developed countries. There are real estate developers that have to get certification from authorities in these countries to affect that radon in the house build and sold by them is within the safe permissible limits. 


\section{Sources of Radon: Where does Radon Comes From?}

Basically, it is the presence of uranium and radium in earth's crust and building materials which is responsible for the production and accumulation of radon in the dwellings. Radon emanates from ground and the surrounding building materials as soil gas and mix with air that we breathe it in the form of its progenies. All rocks mineral and soil inside and on the earth surface, and the building materials contain naturally occurring radioactive materials (NORM) like uranium and thorium, in small amounts of the order of parts per million (ppm). Global average of uranium and thorium content in the earth crust is about $4 \mathrm{ppm}$ and $6 \mathrm{ppm}$ [11]. These elements have very long half-life of about $4.5 \times 10^{9}$ years for Uranium $\left({ }_{92} \mathrm{U}^{238}\right), 7.04 \times 10^{8}$ years for Actino-uranium $\left({ }_{92} \mathrm{U}^{235}\right)$ and $1.41 \times 10^{10}$ years for Thorium $\left({ }_{90} \mathrm{Th}^{232}\right)$. In spite of decaying continuously, these elements still exist in earth crust that solidified about $6 \times 10^{9}$ years ago. The successive decay products of ${ }_{92} \mathrm{U}^{238},{ }_{92} \mathrm{U}^{235}$ and ${ }_{90} \mathrm{Th}^{232}$ are also radioactive and constitute three well know radioactive decay series. These decay series terminate in stable isotope of lead viz., ${ }_{82} \mathrm{~Pb}^{206},{ }_{22} \mathrm{~Pb}^{207}$ and ${ }_{82} \mathrm{~Pb}^{208}$, respectively. The $88^{\text {th }}$ element of periodic table is radium, which is present in the form of isotopes viz., ${ }_{8} \mathrm{Ra}^{226}$, ${ }_{88} \mathrm{Ra}^{223}$ and ${ }_{88} \mathrm{Ra}^{224}$, respectively in the uranium, actinium and thorium series. The radium decays through alpha activity, the daughter product is radon. Radon isotopes ${ }^{220} \mathrm{Rn}$ and ${ }^{219} \mathrm{Rn}$ originate from the decay of Radium isotopes in the thorium $\left({ }^{232} \mathrm{Th}\right)$ and actinium $\left({ }^{235} \mathrm{U}\right)$ radioactive series as shown below [11].

$$
\begin{array}{r}
{ }_{88} \mathrm{Ra}^{226} \longrightarrow{ }_{86} \mathrm{Rn}^{222}+{ }_{2} \mathrm{He}^{4} \\
\left(\mathrm{E}_{\alpha}=4.77 \mathrm{MeV}, \mathrm{E}_{\gamma}=0.19 \mathrm{MeV}\right) \\
{ }_{88} \mathrm{Ra}^{224} \longrightarrow \begin{array}{l}
{ }_{86} \mathrm{Rn}^{220}+{ }_{2} \mathrm{He}^{4} \\
\left(\mathrm{E}_{\alpha}=5.69 \mathrm{MeV}\right)
\end{array} \\
{ }_{88} \mathrm{Ra}^{223} \longrightarrow{ }_{86} \mathrm{Rn}^{219}+{ }_{2} \mathrm{He}^{4}
\end{array}
$$

In this way, radon gas is produce from radium present in rocks, minerals, and soils. Other radon isotopes produced are ${ }_{86} \mathrm{Rn}^{219}$ and ${ }_{86} \mathrm{Rn}^{220}$, which are Actinon and Thoron respectively. These isotopes of radon are also gas at NTP. All the three isotopes are alpha active but have different half-lives. The half-lives of radon isotopes ${ }_{86} \mathrm{Rn}^{222},{ }_{86} \mathrm{Rn}^{220}$ and ${ }_{86} \mathrm{Rn}^{219}$ are 3.82 days, 55 second and 4 second, respectively. Due to longest half-life of 3.82 days among three isotopes of radon, the ${ }_{86} \mathrm{Rn}^{222}$ isotope produced in the uranium-radium series is most conspicuous. It has more chances to come out of earth`s surface or building materials when produced deep inside while other isotopes ${ }_{86} \mathrm{Rn}^{219}$ and ${ }_{86} \mathrm{Rn}^{220}$ will mostly decay inside before escaping due to their very short half-life. Therefore, mostly we are concerned with ${ }_{86} \mathrm{Rn}^{222}$ isotope when we are talking about radon in the dwellings. However, if there is large amount of ${ }_{90} \mathrm{Th}^{232}$ present inside the earth below the site of the constructed house viz., monazite sands, therefore thoron levels should be considered in calculating the radiation dose received from radon exposure. Hence, this gas produced from radium present in rocks, minerals, soils and building materials seeps out through pores and spaces between soil particles and mix in this surrounding air present in the atmosphere and in the dwellings [7].

\section{How does Radon Causes Health Hazards?}

When we breathe and inhale air, radon gas present in it also enter our lungs along with air thorough respiratory system as shown below in Figure 1.

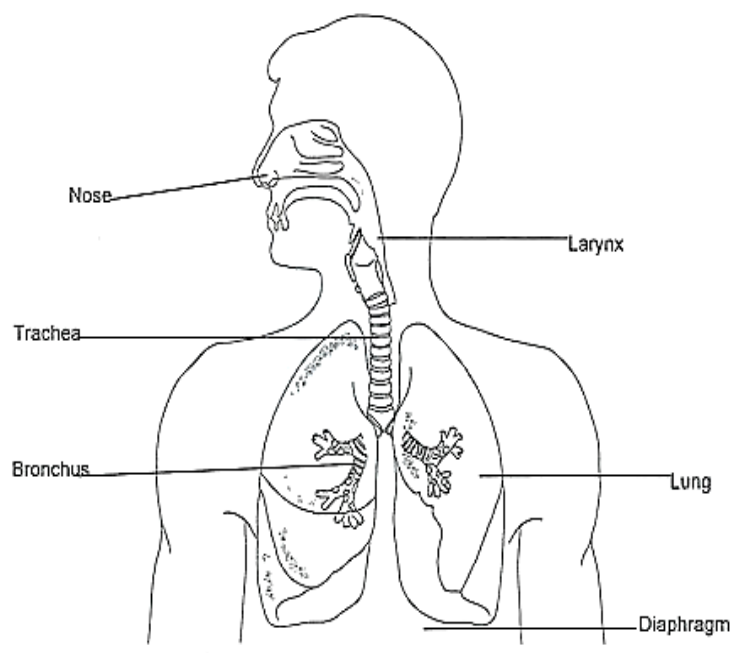

Figure 1: Sketch of respiratory system 
Although most of the radon may exhaled from lungs through diaphragm during breathing but many atoms decay during this process that produce $\alpha$-particles and radioactive daughter product polonium-218 $\left({ }_{84} \mathrm{Po}^{218}\right)$ which in turn also decays giving out $\alpha$-particles and $\gamma$-rays. The daughters of radon are its progenies that emit radiation more quickly and cause greater health risk than radon itself due to their short half-lives. The successive ${ }_{86} \mathrm{Rn}^{222}$ progenies are ${ }_{84} \mathrm{Po}^{218}$, ${ }_{82} \mathrm{~Pb}^{214},{ }_{83} \mathrm{Bi}^{214}$ and ${ }_{84} \mathrm{Po}^{210}$. Here the polonium isotopes are $\alpha$-particles emitters and are most dangerous due to highest energy of these particles and their relative biological effectiveness than $\beta$ rays and $\gamma$-rays.

The ${ }_{86} \mathrm{Rn}^{222}$ present in the surrounding air produces radioactive progenies, which is being charged initially and get attached to very fine dust particles / aerosols present in air. These progenies loaded dust particles enter our lungs during inhalation/ breathing. These radon progenies stick to the inner walls of lungs, bronchial and pulmonary regions of respiratory tract. They continuously emitting $\alpha$-particles indefinitely at inside lungs. These $\alpha$-particle damage and kill the inner cells of the healthy tissues of lungs and bronchi by either creating free radicals or causing DNA breaks and mutations which cause inner wound that are incurable and later turns to be cancerous producing lung cancer.

\section{Radon Entry Routes in the Dwellings}

There are many entry routes in the dwellings as follows:

$>$ Cracks in the floors \& walls.

$>$ Construction joints.

$>$ Gaps in the suspended floors.

$>$ Gaps around service pipes and sump pump.

$>$ Cavities in the walls having trapped air.

$>$ Underground water supply.

$>$ Liquid petroleum gas (LPG) used for cooking.

\subsection{How to Know Radon Levels in The Dwellings}

Radon $\left.{ }_{86} \mathrm{Rn}^{222}\right)$, which can only be detected by using sophisticated nuclear instrumentation. In developed countries like USA and Canada, ${ }_{86} \mathrm{Rn}^{222}$ measuring portable equipments are available commercially in the form of kits at affordable price. There are professional radon monitors based on the measurements of alpha radioactivity of air, water and solids available from scientific suppliers. There are two types of methods used to measure radon.

The Active Methods using electronically counting nuclear detectors as scintillation counter, ionization chamber, surface barrier detector, adsorption based charcoal canister etc. The portable electronic and electret radon dosimeters are also commercially available for professional with trade names as Alpha Guard, Radon Scout Plus, and Portable Radon Gas Surveyor (PRASSI) etc.

> The Passive Methods using solid state nuclear track detectors (SSNTDs) as LR115, CR-39 plastic track detectors for registering and counting alpha tracks of radon by optical microscope or spark counter. The specialists are required to complete analysis for determination of radiation dose that absorbed by lungs from radon exposure that is ubiquitous in the nature. The twin cup dosimeters are commercially available in India for such measurements, which have designed and developed by environmental assessment division at Bhabha Atomic Research Centre, Mumbai, India [11]. The radon measurements by this passive technique fitted with LR-115 detectors takes about three months of exposure in the dwellings to get useful quantitative analysis of radiation dose. Presently, there are many laboratories using this technique all around the world. 


\subsection{Variability of Radon Levels in the Dwellings}

The radon and its progeny levels variability in the dwellings depends upon many factors such as ventilation, building materials used, humidity etc. There are following factors that primarily control the variability of accumulated radon in the dwellings.

> Ventilation altered by living habits of occupants.

$>$ Presence of fine dust particles in air of the room (to which the charged progenies get attached and stick to walls thus reducing radon in the room air by altering the equilibrium factor).

> Uranium and radium content in the rocks and soil underlying the construction site.

$>$ Types and origin of building materials used (radon exhalation rates of granites and shales are more than other building materials).

$>$ Radon gas bulk permeability of the soil that in turn depends upon grain size and inter-grain spacing in the soil.

$>$ Absolute pressure difference between radium source in the earth and its surface.

$>$ The under pressure caused by the difference of temperature between the dwellings interior and the external atmosphere.

$>$ The effective diffusion range of radon in the soil and fine building materials.

$>$ The effective open surface area for emission of radon.

$>$ Transient weather conditions, rain, direction of wind and other seasonal variations.

\section{Prevention of Radon Problems}

The transport of radon in indoor air is controlled by the ventilation rate of enclosure, mainly. Increase of ventilation decreases radon levels and vice-versa. The principal ways of reducing radon accumulation in the dwellings are as follows:

$\checkmark$ Keeping the dwellings fairly ventilated with windows open so that increased ventilation reduces the radon accumulation.

$\checkmark$ Sealing the cracks in floors and walls with impermeable enamel points.

$\checkmark$ Keeping the indoor walls painted with enamel paints to avoid exhalation of radon materials of the walls and ceilings.

$\checkmark$ Subsoil depressurization/soil suction by under floor ventilation (primarily it uses a bent pipe system fan that pulls radon gas from beneath the house and vent it to the outside).

$\checkmark$ Installing radon sump system in the basement.

$\checkmark$ Installing a positive pressurization or positive supply of ventilation using exhaust fans to pump outside air into the room creating slight excess pressure. Leakage will then be outwards.

$\checkmark$ Using radon barrier or a sheet of plastic in crawl space and by vent pipe and fan to draw radon from under the sheet and vent it to outside.

\section{Conclusions}

The long-term integrated indoor radon measurements have been carried out by passive detectors all over the world. In these detectors, the methodology depends upon the $\alpha$-particles track registration. This method is highly reliable and sensitive for such measurements. These studies are very useful in the understanding of the main sources of indoor radon and their health risks, and various factors that are influencing it. Therefore, keeping in view of the detrimental effects of radon and its progeny in human environment have become very important from radiation and health protection point of view.

\section{How to Cite this Article:}

M S Khan, "Radon in the Dwellings: Causes and Prevention", International Annals of Science, vol. 3, no. 1, pp. 1-5, Nov 2017. doi: 10.21467/ias.3.1.1-5

\section{References}

[1] UNSCEAR (United Nations Scientific Committee on the Effects of Atomic Radiation): Sources, effects and risks of Ionizing Radiation. United Nations, New York, 2016.

[2] Khan, M.S., Zubair, M., Verma, D., Naqvi, A.H., Azam, A., Bhardwaj, M.K. The Study of Indoor Radon in the Urban Dwellings Using Plastic Track Detectors. 
Khan, Int. Ann. Sci.; Vol. 3 Issue 1, pp: 1-5, 2017

Environmental Earth Sciences, vol. 63, no. 2, pp. 279282, 2011.

[3] Abd-Elmoniem, A.E. A study of indoor radon levels and radon effective dose in dwellings of some cities of Gezira State in Sudan. Nuclear Technology and Radiation Protection, vol. 29, no.4, pp. 307-312, 2014.

[4] Khan, M.S., Azam, A. Measurements of Indoor Radon, Thoron and their Progeny Using Twin Cup Dosimeters in Rural Areas of Northern India. Environmental Earth Sciences, vol. 71, no. 3, pp. 1319-1325, 2014.

[5] Farid, S.M. Indoor radon in dwellings of Jeddah city, Saudi Arabia and its correlations with the radium and radon exhalation rates from soil. Indoor and Built Environment, vol. 25, no. 1, pp. 269-278, 2016.

[6] Kumar, M., Aagrawal, A., Kumar, R. Study of radon, thoron and their progeny levels in indoor environment of Firozabad city in U.P., India. Journal of Radio analytical and Nuclear Chemistry, vol. 302, no. 3, pp. 1475-1479, 2014.

[7] Verma, D., Khan, M.S. Assesment of indoor radon, thoron and their progeny in dwellings of Bareilly city of Northern India using track etch detectors. Romanian $J$. Phys., vol.59 no. 1-2, pp. 172-182, 2014.

[8] Hashim, A.K., Mohammed, E.J. Measurement of radon concentration and the effective dose rate in the soil of the city of Karbala, Iraq. J. Radiation and Nuclear Applications, vol. 1, no. 1, pp. 17-23, 2016.

[9] Miles, J.C.H., Howrath, C.B., Hunter, N. Seasonal variation of radon concentration in UK homes. Journal of Radiological Protection, vol. 32, pp. 275-287, 2012.

[10] Mayya, Y.S., Mishra, R., Prajith, R., Gole, A.C., Sapra, B.K., Chougaonkar, R.R., Nair, K., Ramola, C., Karunakara, N., Koya, P.K.M. Deposition based passive monitors for assigning radon, thoron inhalation doses for epidemiological studies. Radiation Protection Dosimetry, vol. 152, no. 1-3, pp. 18-24, 2012.

[11] Khan, M.S. "Study of radon and radium in the Natural environment using plastic Track detectors" Ph.D. thesis submitted to Aligarh Muslim University, Aligarh, 2012.
Publish your research article in AIJR journals-

$\checkmark$ Online Submission and Tracking

$\checkmark$ Peer-Reviewed

$\checkmark$ Rapid decision

$\checkmark \quad$ Immediate Publication after acceptance

$\checkmark \quad$ Articles freely available online

$\checkmark \quad$ Retain full copyright of your article.

Submit your article at journals.aijr.in

\section{Publish your books with AIJR publisher-}

$\checkmark$ Publish with ISBN and DOI.

$\checkmark$ Publish Thesis/Dissertation as Monograph.

$\checkmark$ Publish Book Monograph.

$\checkmark$ Publish Edited Volume/ Book.

$\checkmark$ Publish Conference Proceedings

$\checkmark \quad$ Retain full copyright of your books.

Submit your manuscript at books.aijr.org 